\title{
The Last Legislative Election of An Iowa United States Senator
}

\author{
By Leslie E. Francis
}

To ThE Annals Editor: I was pleased, Emory, when you asked me to tell the story of the last election of a United States senator by the legislature of Iowa. I anticipated pleasure and some excitement in preparing the article for you. It is now completed and I am writing the END at the Beginning!

It has been fun to bring back the memories of forty-one years; but an occasional tear has fallen as I have thought of those great and good men, now nearly all gone to their reward. Almost alone I look back upon that long winter of 1911, when we marched from senate to house each day seeking in joint session to agree upon a man to represent lowa in the senate of the United States.

At last, on the 12th day of April, 1911, conflicting minds met and William S. Kenyon, of Fort Dodge, was elected to faithfully serve Iowa as senator for a half-score of years.

I have examined records and newspapers to confirm my memory, but the events of January, February, March and half of April, 1911, were so fixed in my mind that little confirmation was required.-AurHor.

\section{Story of Nineteen Eleven}

A few years after my admission to the practice of law I was in Fort Dodge with some small matter to present to the court. The courtroom was well filled with spectators and a very large number of lawyers. I did not see the judge-in fact did not know who was holding court there that day. Presently came a loud knock on a closed door at the south-east corner of the room and a bailiff ordered everyone to stand. Then the door opened, a man stepped into the courtroom, and the bailiff opened court. I was deeply impressed with this man. I thought:

"He is awfully young to be a judge of the district court."

"He is certainly a fine looking man." 
"I like that fellow."

"I would trust that man anywhere."

That man was Judge William S. Kenyon.

Elsewhere I had found the judge down among the attorneys before court opened. In this instance Judge Kenyon's court opened with all the dignity and aplomb of the Supreme Court of Iowa. It did not appeal to me as an excessive evidence of power, but rather an act of a man who knew his place and filled it. This judge stood for a moment looking over the courtroom with a friendly smile, then took his seat on the bench and in a moment the business of the term was in full swing. For some reason I had never forgotten that day. Many years passed before I again met him and he was then a candidate for election to the senate of the United States.

\section{A Youth's GLoRIFIEd Idols}

My father was an old soldier; in fact, I was an old soldier in spirit. From my earliest youth I had been thrilled by the stories told by the old soldier, then a power in the land. I walked miles to attend old soldiers' "Camp Fires." The railroad had built a very wonderful hotel on the south banks of Spirit Lake, later torn down, and the "great" of the land came there in summer. Often I would walk from the farm to this hotel, just to look for a few moments upon the men who represented the government of the United States. Sometimes one of those great men would attend an old soldiers' "Camp Fire" and speak. I managed to be present at such an event. One such speaker impressed me above all others. He was a congressman from Tipton, Iowa, very young, very handsome, and a speaker the equal of any person I have ever heard.

He stood before the heights, his to surmount, but the temptations of Washington overcame him and he fell. He enters this recital for reasons which will appear as you read on.

He was Bob Cousins.

At Spirit Lake the second Chautauqua in the land 
was organized. For a dozen years it prospered. No man was too great to refuse to grace its platform. I missed no entertainment offered and was thrilled to my marrow by the splendid oratory, the entrancing music, the plays produced upon that stage. Of all those who reached my heart was a young congressman from Fort Dodge. He enlivened with wit, he touched your soul with pathos, he lifted the spirit with words.

He debated upon our platform with another young congressman from Missouri. Their political beliefs were widely apart, they hammered each other without gloves, they drew people for miles around, and none felt that the admission charged was too much.

The young congressman from Fort Dodge was Jonathan P. Dolliver.

The young congressman from the state to the south was Champ Clark.

Upon the lives and words of such men was my youth passed in glory.

You may wonder why I tell you of these men in this story of the last election by the legislature of a United States senator. Read on and you will see how it would be impossible for me to omit one of them to me they are so much a unit that to leave one out would make dreary and unprofitable this story I am about to tell.

\section{The Senatorial Succession}

Senator Gear died in 1900 and. Governor Shaw appointed Mr. Dolliver to the senate. There he served with distinction. He passed on and Governor Carroll named Lafe Young of Des Moines to take Mr. Dolliver's seat in the senate.

Then came the deluge!

The Republican party was torn into two rival camps - Standpatters and Progressives. Albert B. Cummins had become Governor, and after two terms sought a third. George D. Perkins, of Sioux.City, had been in congress from the old eleventh district.. $\mathrm{He}$ wänted to be governor of "Iowa.: "And so these. gianits -of the hust- 
ings met in mortal combat. Cummins did not spare his opponent - Perkins fought in the spirit of the gladiator, "Lay on McDuff, and damned be him that first cries Hold, Enough!" Cummins' voice gave out toward the end of the campaign and Perkins closed with the announcement that "his voice and his CONSCIENCE" were still in good order.

I speak of this conflict because of its direct connection with the long winter of marching and countermarching from senate to house and back, with the daily roll call upon election of a United States senator; for the memories and the wounds of 1906 still waxed strong and hot in the short winter days of 1911.

In one thing at least, it was felt that both Standpatter and Progressive could agree - that was a memorial service for Senator Dolliver. And so when I was asked to be chairman of the committee for arranging this service, and I was happy to accept, I remembered those debates at Spirit Lake and the speeches before Republican conventions, but above all, those occasions when Dolliver, enlivened by a few draughts from the cup that cheers, would take the floor at private meetings in his rooms. He would walk back and forth for hours, speaking with all the eloquence that graced the halls of congress, upon every subject that entered his mind at the moment, from the Glory that was Greece to the Decline and Fall of Rome! And persons who listened to one of these monologues will, I am sure, still remember.

As chairman of the committee it was my duty to aid in the selection of a speaker - someone who could rise equal to the great occasion we had planned. Many were suggested. Finally Representative Zeller of Madison county came to me with a plea for Bob Cousins. He told me that Bob had risen above the temptations of his Washington days, and that this honor would give him new courage. In thought I was wafted back to the years of my youth when Bob Cousins and his eloquence brought forth "rebel yells" from the old sol- 
diers assembled upon the banks of our dear lakes, and I pictured in my mind the thrill's when life was all before me. I accepted and Bob Cousins became our speaker. ${ }^{1}$

The day came and Bob was escorted before the legislature. Senator Larrabee led Bob to the speaker's stand. He was greeted with great applause. No one ever faced a finer audience or had a more splendid chance to rise again to the heights. But his old enemy was again in control; and Bob failed.

Mr. Cousins and Mr. Dolliver had been in the national congress together. They had formerly been much of the same opinion upon many public questions, but had drifted apart. Mr. Cousins took that occasion to assail Mr. Dolliver. It was a very amazing and pitiful affair. Had Mr. Dolliver been living and there to protect himself, such an attack might under some circumstances have been excusable, but $\mathrm{Mr}$. Dolliver was dead, this was a memorial. I could not avoid a feeling of personal responsibility.

When the meeting was adjourned Senator Larrabee and I took Mr. Cousins' printed address, for he had prepared and had it printed for distribution, and struck out every objectionable statement. Today I went over to the Historical building and reread that address, as it now appears in the record. I was amazed to find it to be a perfect specimen of the orator's art. I have seldom read anything better. It is a masterpiece, a credit to any orator of any nation or time. My memory had fastened itself only upon the unfortunate digressions of the speaker. Fred Beckman, then reporter for the Register, told the story of that day. Mr. Cousins is dead. I will not say more upon that day of blasted opportunity. I ask that Mr. Beckman, now in the editorial chair at Knoxville, Iowa, again read that address, robbed of its errors and tell me if he too does not feel today that Bob Cousins was the Master Orator, grasping for Glory but failing just when triumph was in his

${ }^{1}$ Chairman Francis introduced Mr. Cousins, Journal House of Representatives, (1911); p. 1049. 
hands. To reread that speech today, when time has in a measure made it possible to forget the distress of that day long ago, will brighten the soul! ${ }^{2}$

Both Senator Cummins and Senator Young were on the platform that day. I felt that something should be done to save the program. So I called upon Senator Cummins to speak. No such speech was on the program and I am sure that Senator Cummins had no idea that he would be called upon. I had heard him many times, but never before had he ever approached the great address he then gave. It was thrilling. It lifted every person in that vast audience from dismay to enthusiasm. As I looked out over that great gathering I saw grief change to joy. No orator ever made so great a change in so few moments.

I then asked Senator Young to speak. I had never heard him before, but he rose to the occasion and made a very fine address. I had a new respect for him and a much higher regard for the man he proved himself to be that day of victory over defeat. Those speeches are not printed in the journal, but did appear in part in the Register and Capital. As I read them today they did not seem to me to be so great or so wonderful as on that day forty-one years ago, when two fine Americans came to our rescue in a moment of sadness and distress.

You may now understand why I have felt it necessary to bring those three great citizens of Iowa into this picture. With all three in, it is to me a symphony; with either omitted I could not tell the moving story of that long winter's contest.

\section{The Senatorial Candmates}

In due course came the day when a vote must be taken on the election of a senator. - In one candidacy I was much interested: When I was a boy on the old Tusculum farm my parents subscribed to two publications - the Spirit Lake Beacon and the New - York - Address by Robt. G. Cousins, Dolliver Memorial, Journal House of Representatives, (1911), pp. 1050-55. 
Ledger. (I may be excused if here I interpolate that by the agency of an older brother occasional copies of the Police Gazette, with pictures of the Boston Strong Boy and the amply developed ladies of that age, came our way.) My mother was devoted to the Beacon. My birth had appeared in its columns. I never knew of a selfish act by her, save in respect to the Beacon - she wanted to be the first to read it and would hide it until she could do so.

The editor of the Beacon was a man by the name of A. B. Funk. He was exceedingly well known by every politician in the state. His editorials were more influential upon the public policy in Iowa than any others. He was not an orator - in fact, he very reluctantly took the platform upon any occasion, but the printed word was adorned by his skill. He had served twelve years in the state senate from our district. I felt it a great honor to take his old post in the senate, and was the one to urge his candidacy for election to the United State senate. When he finally decided to run he was kind enough to ask me to manage his campaign.

Mr. Funk was a convinced and convincing Republican. He did not hide his views. In his opinion the Grand Old Party carried in its ranks just about all the virtues of organized society. Such crumbs as were floating elsewhere were but derelict, waiting for the next storm to sink them from view. Hence Mr. Funk carried in the Beacon a standing column headed by a strident rooster, symbolizing the Republican party. Beneath that bird with its outspread wings appeared the names of all candidates of the Republican party from president down. When the next year after I became a lawyer, at 23 years of age, my name was there as the candidate of the Republican party for county attorney of Dickinson county, my pride was boundless. I was proud to be Mr. Funk's manager, although woefully ignorant and inexperienced in such matters. I was simply plain scared! But guided by Mr. Funk and his friends, the clouds dispersed in part and my fright gradually passed. 
That contest proved to be the last in which election of a United States senator was before the legislature from thence the people by their direct votes determined all our public officials. When I look backward and compare the men elected under the old method with those resulting from the new, I am not. entirely sure that we Progressives accomplished the mellennium, as we then firmly believed, in establishing the primary!

It will aid you whose memory does not go so far into the past, if I now tell you a little about some of the men who loom large to me in the story of those short days but long winter nights.

Senator Joe Allen of Pocohontas was the manager of the Kenyon campaign. He was a big jovial fellow from the broad prairies of northwest Iowa. His smile was contageous and pleasing. He seemed to be in agreement with the other fellow but never to the extent of changing his mind. The most determined bulldog had nothing on old Joe when it came to sticking tight. To him Kenyon owed his success more than to any combination of others. We were old friends and often in agreement. The most pitiful thing in all that session was to see Joe Allen carrying his beautiful little girl, with her braces and feeble legs, crippled by infantile paralysis, as polio was then called. I could sympathize with him, perhaps more than anyone else, for my own little lad in a terrible seige of pneumonia had suffered the loss of $90 \%$ vision.

A gentleman of even greater firmness of purpose was an old fellow, Captain Brown of Decatur. This senator was in some ways the leader of the horde of Standpatters who obstructed our road to success. He was an old soldier, entering the war at its beginning as a private, emerging four years later as a captain. $\mathrm{He}$ was almost six feet tall, very broad of shoulder, weighing more than 250 pounds and carried an attitude calculated to send all opponents to shelter.. He served all through the Civil war, with :Grant at Donnellson and 
Vicksburg, Thomas at Chickamauga, Sherman at Atlanta and beyond. If his martial mein during the war was at all similar to that in this contest, I am no longer surprised that the South succumbed!

He seldom raised his voice on the floor of the senate, but upon those daily marches from senate to house he permitted all to share with him his knowledge that all Progressives were illegitimate offspring of the devil! He would swell with rage until he seemed twice as big, adding another hundred pounds! The pathway from senate to house fairly trembled with his ponderous step and the air rose in wierd waves as his voice cascaded to the gilded dome. Some of the scantily clad ladies whose portraits adorned the rotunda halls were observed to noticeably shudder as the captain passed below them. He interested me and I liked him. To me he was a relief from a long winter of discontent.

I will mention another senator whom I knew well. He was from Hamilton county and bore the name of Cady Chase. $\mathrm{He}$ was really an awfully nice fellow and I liked him very much. When it was known that he was to speak, chairs were brought in to hold the crowd. He could make day seem dark and night bright and glowing. He was the exact opposite of the two men I have just described. His opinions varied with the day. His natural course was opposition to whatever ought to be advocated by others. He refused to allow his picture among the other forty-nine senators, but relented when he noted how handsome some of us looked. He was sometimes a Standpatter, at other times a Progressive. But denied that he was either, and insisted that he was independent of all ties. Yet you could not avoid liking him. His retorts in debate were proverbial, not necessarily upon the subject in discussion, but certain to bring applause from the audience.

I might include a host of others in this brief picture of the men who finally, upon the very last day of .the session; elected a United States senator. But this is 
sufficient to give you an idea as to the events of that Hundred Days Battle.

\section{The Balloting Begins}

Under the provisions of the Constitution of the United States, should a vacancy occur in the House of Representatives, a special election must be held, but if the vacancy was in the senate, the governor of the state could appoint a senator, who would serve until the legislature elected a successor or the legislature adjourned without electing anyone. That was the law when Mr. Dolliver died and continued to be the law until adoption of the senatorial direct primary. Therefore, it was incumbent upon the Thirty-fourth General Assembly to elect a senator, or Iowa would have but one senator in congress. The long contest made this point of great importance and was no doubt the fact which finally brought enough Standpatters over to bring about an election.

It was necessary that the election be made at a joint session and by a majority of all members whether actually voting or not. And joint sessions were always held in the house chamber. As a result the senators had to walk over from the senate chamber, usually led by the lieutenant governor. The house members always rose respectfully, whether they felt that way or not, and stood as the senators entered. The lieutenant governor then presided and a roil call was had to determine if a majority was in attendance, in which case the business of the joint session followed.

On that first joint vote the following persons were voted for: Claude R. Porter, 53 votes; Layfette Young, 32 votes; W. S. Kenyon, 22 votes; A. B. Funk, 21 votes; H. W. Byers, 14 votes; Guy A. Feeley, 7 votes; Warren Garst, 6 votes; Carl R. Franke, 2 votes. Mr. Porter was the Democratic candidate and during the long weeks which followed, save on one day when Frank A. O'Conner was given that vote, he received the Democratic vote, consistently and faithfully. On the very last roll call his vote was 51 . I shall not hereafter 
mention Mr. Porter's candidacy, nor the vote given him, but will give my attention entirely to the Republicans and the stringent and often acrimonious contest which divided them into two warring camps. ${ }^{3}$

As I have stated, Senator Funk from my home town of Spirit Lake was a candidate and for him I did the best I knew. On February 8th, 1911, the Kenyon vote dropped to 7 and Mr. Funk's rose to 55, but this was only a parting gesture, for Mr. Funk had decided to withdraw and that large vote was given him in recognition of a fine gentleman and a worthy man. When Mr. Funk dropped out of the contest my little boy, who had attended every joint session and looked upon Mr. Funk as almost equal to his own father, hid in a vacant room and wept briny tears. Had his wishes prevailed the Constitution would have been abrogated right then and there and Mr. Funk declared the winner.

\section{Young and Funk Drop Out}

Generally speaking, the Standpatters had consistently voted for Mr. Young, but on February 15 Judge Deemer of the state supreme court was presented as a compromise candidate, and thereafter they voted for him. The contest had been narrowed by the withdrawal of all candidates except Mr. Kenyon and Judge Deemer, and thus it stood day after day and week after week. Around the middle of March Mr. Kenyon's vote rose to 65 and there stopped. At the first roll call on the

${ }^{3}$ The senatorial deadlock was the second in the history of the state, the first being in 1846, when no senators were elected, and the state was without representation in the U.S. senate the first two years of its existence. This time it lasted to the very final day of the legislative session, and sixty-eight ballots were taken, sixty-seven in the joint sessions. A field of seven Republican candidates appeared on the first ballot.-Journal House of Representatives, (1911), p. 182.

Feely dropped out after the first ballot, and Byers and Franke after the fifth. Funk threw all his strength to Kenyon on the twelfth, thirteenth, and fourteenth ballots, but without avail, and the compliment was returned on the three succeeding ballots, without effect. Funk then withdrew after the nineteenth ballot. The Young votes went to Judge Horace E. Deemer on the thirty-third ballot, and mostly remained with him to the end. Senator Garst also dropped out at this time. With the entry of Judge Deemer, the Garst-Funk-Byers strength divided, part of it going to 
12th day of April his vote went up to 76 , but he still lacked a majority.

Then ensued an exciting contest as to procedure. That day had been fixed as the final day of the session. The Standpatters felt that if another vote were taken, Kenyon might win and therefore attempted to prevent the taking of a second ballot. The Progressives thought that another vote would give Kenyon the senatorship. The opposition to Kenyon was plainly slipping.

Debate was not allowable, but it was at this point that my good old friend, the captain and senator from Decatur, rose and bellowed with great intensity that "traitors to the cause of decency in government might abandon Judge Deemer and slink over to enjoy the loaves and fishes," but as for him he "would stay right there and vote for the principle and right until hell froze over."

The captain's appeal did not prevent defeat of the motion to adjourn and the second roll call was then held. On the second call $\mathrm{Mr}$. Kenyon received 85 votes, enough to elect him, and so after more than THREE MONTHS, the fight was ended. ${ }^{4}$

Mr. Kenyon had been in Washington, where he held a position in the justice department, but knowing that an election was certain to occur before the legislature adjourned, he was in Des Moines on that fateful April 12, 1911. He was immediately invited to come

- Roll call on final vote for U.S. senator, Journal House of Representatives, (1911), p. 1924.

Deemer and part of it to Kenyon; but gradually it all withdrew from Deemer and went to Kenyon.

The Democrats confined their votes to Democrats, voting chiefly for Claude R. Porter, D. W. Hamilton, and F. A. O'Conner, but individual votes were cast for Judge M. J. Wade, Senator Clarkson, Nick Reed, and other Democrats.

Senators Henry L. Adams of Fayette county, and Charles G. Saunders of Pottawattamie county, having previously voted for Deemer, sought to break the deadlock April 12, on the next to the last ballot, by casting their votes for Kenyon. On the last ballot Sen. H. R. Chapman of Cedar county, and Rep. Geo. W. Van Camp of Adair county, led the final stampede for Kenyon, breaking the deadlock by changing their votes from Deemer, not being willing to have the legislature adjourn without electing a senator. After Kenyon's election was assured, a group of seven other ${ }^{2}$ Deemer votes changed to Kenyon.-EDrron: 
before the joint session. When he appeared with the committee sent for him, the great crowd rose and the cheers rocked the building as perhaps never before in it's history. After three months of bitter contest the relief was intense and everyone wanted to shout and dance and cheer, all perhaps except our friend the captain! ${ }^{5}$

It did not impress me then and it does not impress me today as I read the new senator's speech, as being a very profound speech, but it was cheered to the echo. Judge Deemer was then sent for and he made a speech, but a rather poor one for so great a man. ${ }^{6}$ I scarcely knew Mr. Kenyon, but was well acquainted with Judge Deemer. I looked upon him as one of the most able judges our supreme court had ever had. I voted for him many times, but was happy when the young judge of my more youthful days in the Fort Dodge courtroom, became a great senator from Iowa to the national congress.

We who had taken part in that long struggle and now saw the home fires blazing in the distance, cheered everything those men said - cheered loudly and happily.

Out of that happily ended contest I doubt if a single enmity was created that time did not soften and finally erase. Today the Republican party has no such divisions as resulted from the militant and always dominant leadership of Senator Cummins.

And so, the last election of a United States senator, except by direct vote of the people, was completed. Great men had been elected by the old method; great men were to be elected by the new. The PEOPLE were thereafter in command.

Always and forever, THE PEOPLE!

'Acceptance by Judge Kenyon, Journal House of Representatives, (1911), pp. 1926-7.

- Address by Judge Deemer, Journal House of Representatives, (1911), pp. 1927-8. 
Copyright of Annals of Iowa is the property of State of Iowa, by \& through the State Historical Society of Iowa and its content may not be copied or emailed to multiple sites or posted to a listserv without the copyright holder's express written permission. However, users may print, download, or email articles for individual use. 